\title{
Properties of Chitinase Activities from Mucor mucedo: Evidence for a Membrane-bound Zymogenic Form
}

\author{
By ANNE M. HUMPHREYS* AND GRAHAM W. GOODAY \\ Department of Microbiology, University of Aberdeen, Aberdeen AB9 IAS, UK
}

(Received 1 December 1983; revised 10 February 1984)

\begin{abstract}
Chitinase activities were detected in the supernatant and microsomal fractions from homogenized mycelium of surface-grown cultures of Mucor mucedo. Most properties of the two preparations were very similar, e.g. $\mathrm{pH}$ optima were 5.65 and 5.55 , respectively, and $K_{\mathrm{m}}$ values were 16.7 and $19.2 \mathrm{mg}$ chitin $\mathrm{ml}^{-1}$, respectively. Neither activity had a cationic requirement, but both were inhibited by $\mathrm{Cu}^{2+}$. Some properties differed. On freezing, the supernatant activity remained constant over $4 \mathrm{~d}$ and then gradually decreased, whereas microsomal activity increased, suggesting that endogenous activation was occurring. Prolonged incubations at $30^{\circ} \mathrm{C}$ also allowed endogenous activation of microsomal activity, which could be prevented by incubation with phenylmethanesulphonyl fluoride. This enzyme activity could also be activated by treatment of the microsomes with proteases such as trypsin. Inactivation occurred after treatment with phospholipases, suggesting that microsomal chitinase requires phospholipidenzyme interactions for activity. Thus the microsomal activity behaved as a membrane-bound zymogen.
\end{abstract}

\section{INTRODUCTION}

It has long been suggested that lytic enzymes may play a morphogenetic role in localized wall softening during the apical growth and branching of fungal hyphae (see reviews by BartnickiGarcia, 1973; Rosenberger, 1979; Gooday \& Trinci, 1980). Chitin is a major structural component of most fungal walls, and so the existence of a chitinase activity with such a morphogenetic role can be postulated. There are many accounts (reviewed by Berkeley, 1979) of fungal chitinases with roles of gross autolysis (e.g. in fruit bodies of Coprinus and Lycoperdon species), of nutrient scavenging and of lysis of other fungal or invertebrate structures, but to date there are few accounts of chitinase activities that may play a role in regulating chitin deposition in cells. Examples include a periplasmic chitinase activity from Saccharomyces cerevisiae (Elango et al., 1982) and a wall-bound chitinase activity from Aspergillus nidulans (Polachek \& Rosenberger, 1978).

Here, we describe characteristics of a membrane-bound chitinase activity from Mucor mucedo which has properties that suggest it is a morphogenetic autolysin involved in hyphal growth. We also include comparative results on a supernatant chitinase activity from the same fungus. The initial observation that led to this work was our apparent failure to prepare microsomal preparations with chitin synthase activity from surface-grown colonies of $M$. mucedo. Mycelium grown in liquid culture yielded chitin synthase activity as expected, but on incubation with UDP- $N$-acetylglucosamine the surface-grown microsomal preparations yielded diacetylchitobiose as the product instead of chitin. On examination this proved to be because they contained a chitinase activity that efficiently degraded the nascent chitin as fast as it was made. Similarly, the inhibitors of chitin synthase from Mucor rouxii (Lopez-Romero et al., 1982) and

Abbreviations: PMSF, phenylmethanesulphonyl fluoride ; 3,4-DNP-TNAC, 3,4-dinitrophenol-tetra- $N$-acetyl- $\beta$ D-chitotetraoside. 
Neurospora crassa (Zarain-Herzberg \& Arroyo-Begovich, 1983) have proved to be chitinases. This coexistence of chitinase with chitin synthase might represent a lytic/synthetic complex with the role of inserting new chitin into pre-existing walls, as is required for branch and septum formation and for hyphal apical extension.

\section{METHODS}

Organism and growth condition. Mucor mucedo (L.) Fresenius (Z46 plus) was grown and maintained on agar plates (composition, w/v: malt extract $2 \%$, mycological peptone $0.5 \%$, glucose $2 \%$, agar $2 \%$ ) at $20{ }^{\circ} \mathrm{C}$. For these experiments the inoculum was a uniform spreading of $2 \times 10^{8}$ sporangiospores in $1 \mathrm{ml}$ on a $9 \mathrm{~cm}$ Petri dish.

Preparation of mycelial extract. After $18 \mathrm{~h}$ growth, the mycelium was harvested, washed with homogenizing buffer [0.1 M-MES, $30 \mathrm{~mm}-\mathrm{MgCl}_{2}, 1 \mathrm{~mm}$-EDTA, $0.25 \mathrm{M}$-sucrose, $\left.\mathrm{pH} 5.55\right]$ and then disrupted after freezing in a $25 \mathrm{ml} \mathrm{X-Press} \mathrm{(A.} \mathrm{B.} \mathrm{Biox,} \mathrm{Jarfalla,} \mathrm{Sweden)} \mathrm{containing} 8 \mathrm{~g}$ wet mycelium and $16 \mathrm{ml}$ buffer. The mycelial plug was thawed and a further $32 \mathrm{ml}$ buffer was added. The disrupted mycelium was centrifuged at $14500 \mathrm{~g}\left(r_{\mathrm{av}} .10 .8 \mathrm{~cm}\right)$ for $15 \mathrm{~min}$ at $4{ }^{\circ} \mathrm{C}$, to get the low-speed pellet. The supernatant was removed and centrifuged at $100000 \mathrm{~g}\left(r_{\mathrm{av}}, 6 \mathrm{~cm}\right)$ for $1 \mathrm{~h}$ at $4{ }^{\circ} \mathrm{C}$. The supernatant was retained and used in enzyme assays. The microsomal pellet was washed in $20 \mathrm{ml}$ assay buffer (0.15 M-MES, $30 \mathrm{mM}-\mathrm{MgCl}_{2}, 1 \mathrm{mM}$-EDTA, $\left.\mathrm{pH} 5.55\right)$ and centrifuged at $100000 \mathrm{~g}$ for $\mathrm{I} \mathrm{h}$ as before. The microsomal pellet was resuspended in 3-4 $\mathrm{ml}$ assay buffer and used for enzyme assays.

Chitinase assays. Two assays were used, a radioactive assay and a chromogenic assay. The first, used for all experiments unless otherwise stated, was based on the method of Molano et al. (1977). Chitosan ( $3 \mathrm{~g}$ ) was acetylated using $25 \mathrm{mCi}(925 \mathrm{MBq})\left[{ }^{3} \mathrm{H}\right]$ acetic anhydride (Amersham). The resulting chitin was washed exhaustively with $50 \%(\mathrm{v} / \mathrm{v})$ acetic acid and then water, and was homogenized to a fine suspension to increase its efficiency as a substrate. It was estimated to be $95 \%$ acetylated using the method of Muzzarelli et al. (1980). The final preparation was stored at a concentration of $33 \mathrm{mg} \mathrm{ml}^{-1}$, in $0.02 \%$ sodium azide.

Unless otherwise stated, reaction mixtures contained $50 \mu 1$ assay buffer, $40 \mu$ enzyme preparation and $10 \mu \mathrm{l}$ $\left[{ }^{3} \mathrm{H}\right.$ ]chitin (approximately $20 \mathrm{mg} \mathrm{ml}^{-1}$, containing $39 \cdot 2 \mathrm{nCi}, 1.45 \mathrm{kBq}$ ). After incubation at $30^{\circ} \mathrm{C}$ for $15 \mathrm{~min}$ with vigorous shaking, $300 \mu \mathrm{l} 10 \%(\mathrm{w} / \mathrm{v})$ trichloroacetic acid was added and the samples centrifuged at $15000 \mathrm{~g}\left(r_{\mathrm{av}}\right.$. $4.2 \mathrm{~cm}$ ) for $12 \mathrm{~min}$ at room temperature. In order to remove any labelled acetate resulting from the action of chitin deacetylase (Araki \& Ito, 1975; Bartnicki-Garcia \& Davis, 1983), $200 \mu$ samples of the supernatant were lyophilized over $\mathrm{KOH}$ pellets overnight at $-40^{\circ} \mathrm{C}$. They were redissolved in $200 \mu \mathrm{l}$ water and counted in $4 \mathrm{ml}$ scintillation fluid [ $667 \mathrm{ml}$ toluene, $333 \mathrm{ml}$ Triton X-100, $4 \mathrm{~g}$ 2,5-diphenyloxazole and 0.1 g 1,4-di-2-(4-methyl-5phenyloxazolyl)benzene]. Trial assays with and without this lyophilization step indicated that the supernatant fraction had negligible deacetylase activity, while the microsomal fraction had a deacetylase activity accounting for about $6 \%$ of the total solubilization of the radioactive substrate.

In some of the experiments, 3,4-dinitrophenol-tetra- $N$-acetyl- $\beta$-D-chitotetraoside (3,4-DNP-TNAC) was also used as a substrate to detect chitinase activity (Aribisala \& Gooday, 1978). Reaction mixtures contained $300 \mu 1$ assay buffer, $\mathrm{pH} 5.5$ or 6.0 (for microsomal and supernatant chitinase, respectively), and $300 \mu 1$ enzyme preparation. After preincubation at $30^{\circ} \mathrm{C}, 60 \mu \mathrm{l}$ substrate, containing $0.5 \mathrm{mg} 3,4-\mathrm{DNP}$-TNAC ml-1 ${ }^{-1}$ was added. The rate of colour release of 3,4-DNP was measured at $400 \mathrm{~nm}$ over $15 \mathrm{~min}$. Due to the turbidity of some samples, a single point assay sometimes had to be used. After incubation at $30^{\circ} \mathrm{C}$ for $15 \mathrm{~min}$, the reaction was stopped by adding $0.75 \mathrm{ml} 0.1 \mathrm{M}$-sodium tetraborate, $\mathrm{pH} 12$. The samples were centrifuged at $15000 \mathrm{~g}\left(\mathrm{r}_{\mathrm{av} .} .2 \mathrm{~cm}\right)$ for $10 \mathrm{~min}$ at room temperature, and the absorbance of the supernatant was read at $400 \mathrm{~nm}$.

Protein concentration was determined using the method of Bradford (1976).

Treatment with cations. Enzyme preparations were obtained as described above, except that $\mathrm{MgCl}_{2}$ was omitted throughout the procedure. Chitinase was assayed in the normal way, except that a range of divalent metal cations, as chloride salts $(15 \mathrm{mM})$, were used in the assay buffer in place of $\mathrm{MgCl}_{2}$.

Treatment with proteases. The proteases used were: trypsin, acid protease (from Aspergillus saitoi) and rennet (from Mucor miehei). Enzyme preparation $(40 \mu \mathrm{l})$ was incubated with $50 \mu \mathrm{l}$ assay buffer, containing $10-150 \mu \mathrm{g}$ protease $\mathrm{ml}^{-1}$, at $30^{\circ} \mathrm{C}$ for $15 \mathrm{~min} ; 7 \mu \mathrm{l}$ of a solution of soybean trypsin inhibitor or pepstatin $\mathrm{A}$, as appropriate, was added and the tubes cooled. The final concentration of inhibitor was twice that of the protease present. Samples were then assayed for chitinase.

Treatment with phenylmethanesulphonyl fluoride (PMSF). Different amounts of PMSF (a serine protease inhibitor) were added to samples of enzyme preparation in an ice bath, to give a final concentration of $2-30 \mathrm{mM}$. The tubes were left on ice for $15 \mathrm{~min}$ with occasional mixing to allow the PMSF to dissolve and then assayed in the normal way for chitinase activity.

Protease assay. Incubation mixtures contained $600 \mu \mathrm{l}$ enzyme and $100 \mu \mathrm{l}$ of a $2 \mathrm{mM}$ solution of chromogenic peptide (Kabi Diagnostica, Stockholm, Sweden), prepared as described by Achstetter et al. (1981). After incubation at $37^{\circ} \mathrm{C}$ for $20 \mathrm{~h}$, the reaction was stopped with $100 \mu \mathrm{l} 50 \%$ acetic acid. The absorbance of 4nitroaniline was measured at $405 \mathrm{~nm}$.

Treatment with phospholipases. Standard reaction mixtures lacking $\left[{ }^{3} \mathrm{H}\right] \mathrm{ch}$ itin were incubated at $30^{\circ} \mathrm{C}$ for $15 \mathrm{~min}$ 
with various phospholipases (Sigma) in a final volume of $90 \mu l$ containing $40 \mu$ l enzyme sample. The final concentrations of each phospholipase added were: phospholipase A, $252 \mathrm{mU}$ per $90 \mu \mathrm{l}$, phospholipase $\mathrm{C}, 160 \mathrm{mU}$ per $90 \mu \mathrm{l}$, and phospholipase D, $250 \mathrm{mU}$ per $90 \mu \mathrm{l}$. After incubation, $10 \mu \mathrm{l} 50 \mathrm{~mm}$-EGTA was added, and the samples were then assayed as usual for chitinase activity. As a control for phospholipase A activity, a parallel series of assays were performed in which the EGTA solution was added before the phospholipase.

\title{
RESULTS
}

\section{Properties of chitinase preparations}

Chitinase activities were detected in the microsomal and supernatant fractions, and there was a low specific activity in the low-speed fraction (Table 1). For microsomal and supernatant fractions, the amount of degradation of the regenerated chitin was proportional to time for approximately $15 \mathrm{~min}$. Longer incubation times resulted in a slowing of the rate of reaction. The initial velocities for this radioactive assay, calculated using the interpolation method of Algranati (1963), were proportional to enzyme concentration. The $\mathrm{pH}$ optima were $5 \cdot 55$ and 5.65 for the microsomal and supernatant preparations, respectively, using tritiated chitin as a substrate; and 5.55 and 6.0 using 3,4-DNP-TNAC as a substrate.

Linear Lineweaver-Burk plots were obtained for both the chitinase activities. The $K_{\mathrm{m}}$ values for both preparations were very similar at $19.2 \mathrm{mg}^{\mathrm{chitin} \mathrm{ml}} \mathrm{ml}^{-1}$ and $16.7 \mathrm{mg} \mathrm{chitin} \mathrm{ml}^{-1}$ for the microsomal and supernatant chitinase, respectively. The values for maximum enzyme reaction velocities differed, at 0.66 and $2.33 \mathrm{nmol}$ diacetylchitobiose formed $\min ^{-1}$ (mg protein) ${ }^{-1}$, respectively. These are the values from one experiment, as the $K_{\mathrm{m}}$ and $V_{\max }$ values were different for each preparation of radioactive chitin, probably due to variation in its physical state.

Both microsomal and supernatant chitinases did not appear to have a specific cationic requirement for activity. Both enzymes, especially the supernatant form, were inhibited by cupric ions, and cobalt ions were slightly inhibitory to the supernatant chitinase activity (Table 2).

\section{Effect of proteases and a protease inhibitor}

When the two chitinases were stored at $-20^{\circ} \mathrm{C}$, supernatant chitinase activity remained stable over $3 \mathrm{~d}$ and then gradually decreased. However, microsomal chitinase activity increased over $7 \mathrm{~d}$ twofold. Similar results were obtained when using 3,4-DNP-TNAC as a substrate. These results indicate endogenous activation of microsomal chitinase, perhaps by proteolytic enzymes. Microsomal chitinase was activated by low concentrations of trypsin at $30{ }^{\circ} \mathrm{C}$ for

\section{Table 1. Typical chitinase activities in $M$. mucedo preparations}

\begin{abstract}
Units are: nmol diacetylchitobiose formed $\min ^{-1}(10 \mathrm{~g} \text { fresh wt tissue })^{-1}$ and nmol diacetylchitobiose formed $\min ^{-1}$ (mg protein) ${ }^{-1}$ for the radioactive assay; and nmol 3,4-DNP formed $\mathrm{min}^{-1}$ (10 $\mathrm{g}$ fresh wt tissue $)^{-1}$ and nmol 3,4-DNP formed $\min ^{-1}$ (mg protein) ${ }^{-1}$ for the chromogenic assay. These results are from one batch of homogenized mycelium, except for the low-speed pellet results which came from a separate preparation. Trypsin-treatment was for $10 \mathrm{~min}$ with $60 \mu \mathrm{g}$ trypsin $\mathrm{ml}^{-1}$ at $30^{\circ} \mathrm{C}$. Each value is the mean of four replicates.
\end{abstract}

\begin{tabular}{|c|c|c|c|c|}
\hline \multirow[b]{2}{*}{ Fraction } & \multicolumn{2}{|c|}{ Radioactive assay } & \multicolumn{2}{|c|}{ Chromogenic assay } \\
\hline & Total activity & Specific activity & Total activity & Specific activity \\
\hline
\end{tabular}

Low speed pellet

Native

Trypsin-treated

$1 \cdot 16$

0.66

0.08

0.04

$1 \cdot 66$

$0 \cdot 10$

Microsomes

Native

Trypsin-treated

1.00

0.46

0.94

0.06

$1 \cdot 50$

0.69

0.63

0.29

Supernatant

Native

$66 \cdot 6$

$2 \cdot 15$

0.96

0.44

Ratio of supernatant 


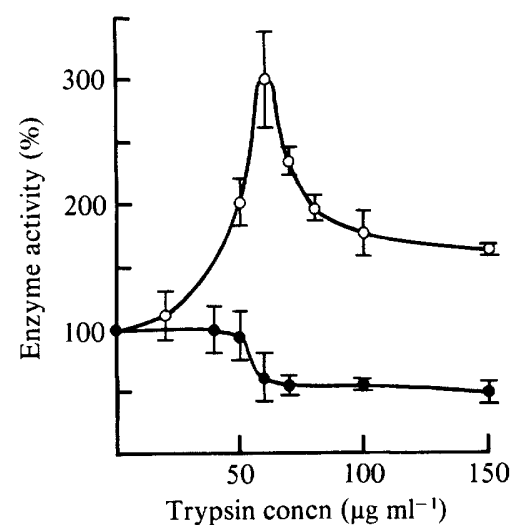

Fig. 1

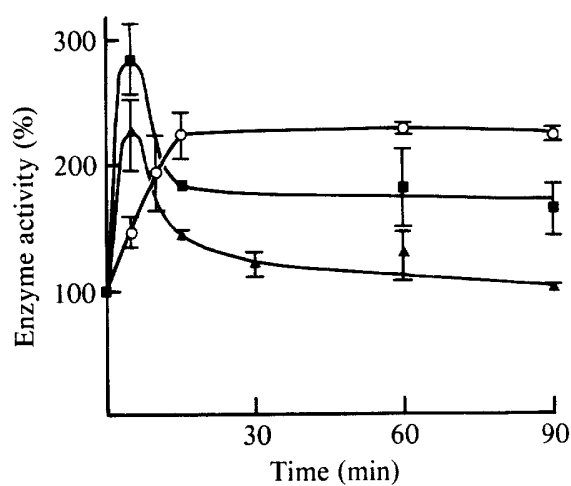

Fig. 2

Fig. 1. Treatment of chitinase from $M$. mucedo with trypsin at $30^{\circ} \mathrm{C}$ for $15 \mathrm{~min}$. $\bigcirc$, Microsomal chitinase; , supernatant chitinase. Bars represent SE of normalized results for 15 replicates; $100 \%$ activity represents 0.56 and $1.34 \mathrm{nmol}$ diacetylchitobiose formed $\mathrm{min}^{-1}$ (mg protein) ${ }^{-1}$ for microsomal and supernatant chitinase, respectively.

Fig. 2. The effect of incubations with and without trypsin at $30^{\circ} \mathrm{C}$ on microsomal chitinase activity from $M$. mucedo. $\bigcirc, 0 \mu \mathrm{g}$ trypsin $\mathrm{ml}^{-1} ; \mathbf{D}, 60 \mu \mathrm{g} \mathrm{ml}^{-1} ; \Delta, 150 \mu \mathrm{g} \mathrm{ml}^{-1}$. Bars represent SE of normalized results from at least eight replicates; $100 \%$ activity represents $1.63 \mathrm{nmol}$ diacetylchitobiose formed $\min ^{-1}$ (mg protein) ${ }^{-1}$.

\section{Table 2. Effects of divalent cations on chitinase activities from $M$. mucedo}

Values are the means of 10 replicates $\pm \mathrm{SE} ; 100 \%$ activity represents 0.60 and $2.63 \mathrm{nmol}$ diacetylchitobiose formed $\mathrm{min}^{-1}$ (mg protein) ${ }^{-1}$ for microsomal and supernatant chitinase, respectively.

\begin{tabular}{lcc} 
& \multicolumn{2}{c}{ Percentage activity } \\
\cline { 2 - 3 } Cation & Soluble chitinase & Microsomal chitinase \\
None & $100 \cdot 0 \pm 5 \cdot 0$ & $100 \cdot 0 \pm 11 \cdot 6$ \\
$\mathrm{Ca}^{2+}$ & $91 \cdot 4 \pm 18 \cdot 0$ & $93 \cdot 3 \pm 2 \cdot 7$ \\
$\mathrm{Co}^{2+}$ & $79 \cdot 5 \pm 9 \cdot 1$ & $98 \cdot 3 \pm 2 \cdot 5$ \\
$\mathrm{Cu}^{2+}$ & $5 \cdot 7 \pm 7 \cdot 1$ & $53 \cdot 3 \pm 15 \cdot 0$ \\
$\mathrm{Mg}^{2+}$ & $103 \cdot 3 \pm 3 \cdot 5$ & $116 \cdot 7 \pm 14 \cdot 0$ \\
$\mathrm{Mn}^{2+}$ & $94 \cdot 3 \pm 12 \cdot 5$ & $100 \cdot 8 \pm 10 \cdot 0$ \\
$\mathrm{Zn}^{2+}$ & $85 \cdot 4 \pm 11 \cdot 0$ & $100 \cdot 0 \pm 9 \cdot 5$
\end{tabular}

$15 \mathrm{~min}$, with maximum activation at $60 \mu \mathrm{g}$ trypsin $\mathrm{ml}^{-1}$ (Fig. 1). At higher concentrations enzyme activity began to decrease, presumably as the rate of enzyme inactivation outweighed activation. Supernatant chitinase activity, however, remained unaffected by the treatment with trypsin up to concentrations of $40 \mu \mathrm{g} \mathrm{ml}^{-1}$. As the concentration increased, activity decreased, presumably as the enzyme succumbed to proteolytic inactivation (Fig. 1). Figure 2 shows the effect of incubations with trypsin at $30^{\circ} \mathrm{C}$ on microsomal chitinase activity, in comparison to endogenous activation. This was slower to reach its peak than the trypsin-treated samples, but activity then remained constant. With the trypsin-treated samples, activity peaked after $5 \mathrm{~min}$ and then decreased, presumably as degradation outweighed activation; this occurred more rapidly when the trypsin concentration was increased. Very similar results were obtained using rennet and acid protease. Thus, part of the microsomal chitinase activity was zymogenic.

In enzyme preparations made at different times, the extent of zymogenicity varied. The ratio of supernatant chitinase activity to trypsin-treated microsomal chitinase activity was constant, but the ratio of supernatant to native microsomal activity varied. Presumably this represented variations in the extents of endogenous activation during the preparation procedures. The activity in the low-speed pellet (chiefly cell walls) was inactivated by trypsin (Table 1), and thus in this respect was like the supernatant enzyme. 


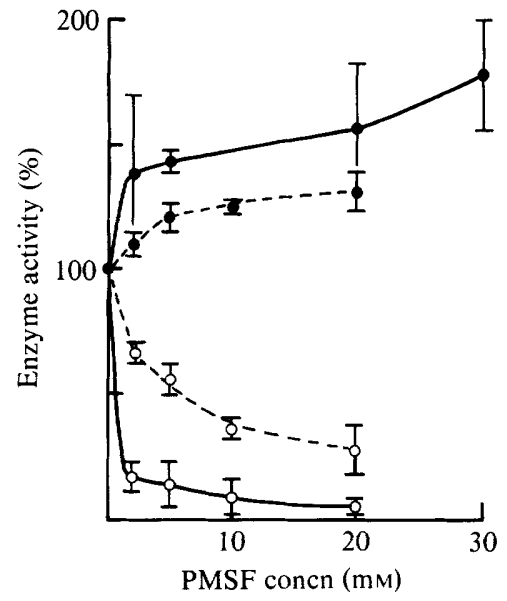

Fig. 3

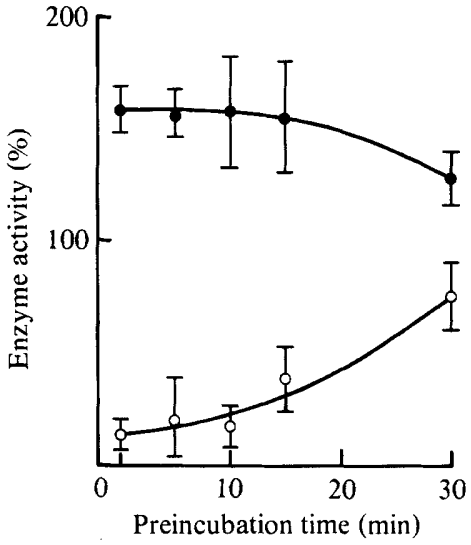

Fig. 4

Fig. 3. Effect of PMSF on chitinase activities from $M$. mucedo. $\bigcirc$, Microsomal chitinase; supernatant chitinase. Bars represent SE of normalized results from at least eight replicates. Solid lines represent the radioactive assay; dashed lines represent the chromogenic assay. Preparations are from separate enzyme extractions; $100 \%$ activity represents 1.06 and $1.86 \mathrm{nmol}$ diacetylchitobiose formed $\mathrm{min}^{-1}$ (mg protein $)^{-1}$ for microsomal and supernatant chitinase, respectively, for the radioactive assay, and 0.6 and $1.69 \mathrm{nmol}^{3,4-D N P}$ released $\min ^{-1}$ (mg protein) ${ }^{-1}$ for microsomal and supernatant chitinase, respectively, for the chromogenic assay.

Fig. 4. Effect of preincubations with $15 \mathrm{mM}$-PMSF on chitinase activity from $M$. mucedo. $O$, Microsomal chitinase; $\bigcirc$, supernatant chitinase. Activity is shown as a percentage of the control value $(100 \%)$ which consisted of enzyme minus PMSF, which was not subjected to a preincubation. After the preincubation, the samples were assayed for chitinase activity for $15 \mathrm{~min}$ at $30^{\circ} \mathrm{C}$. Bars represent $\mathrm{SE}$ of normalized results for at least eight replicates; $100 \%$ activity represents 3.48 and 1.03 nmol diacetylchitobiose formed $\min ^{-1}$ (mg protein) $)^{-1}$ for microsomal and supernatant chitinase, respectively.

Assays in the presence of the serine protease inhibitor, PMSF, gave different results for the two preparations. The microsomal chitinase preparation showed a reduction in enzyme activity, by $90 \%$ at $15 \mathrm{mM}-\mathrm{PMSF}$, but the supernatant chitinase preparation showed an increase in activity of $50 \%$ at $15 \mathrm{~mm}$-PMSF (Fig. 3). This phenomenon was confirmed with the chromogenic assay (Fig. 3), in this case with a $70 \%$ reduction and a $25 \%$ stimulation, respectively, at $15 \mathrm{mM}$-PMSF. (The quantitative difference between the radioactive and chromogenic assays reflects the differing extents of zymogenicity that we observed in different preparations.) The PMSF appears to be inhibiting endogenous activation of the zymogen. Preincubations with $15 \mathrm{mM}-\mathrm{PMSF}$ at $30^{\circ} \mathrm{C}$ also had very different effects on the two enzymes. The activity of the microsomal preparation was strongly suppressed, again presumably by inhibition of its activation, but it increased to some extent after further incubation (Fig. 4). However, in the case of supernatant chitinase there was initially a $50 \%$ increase in activity, and this activity remained constant over $15 \mathrm{~min}$.

Endogenous proteolytic activities were investigated only in the microsomal preparations. Of the peptides used, six gave a positive reaction, with varying degrees of intensity (Table 3), indicating the presence of at least six different proteolytic activities.

\section{Effect of phospholipases}

The addition of phospholipases to supernatant chitinase preparations had no significant effect on enzyme activity, but the microsomal chitinase activity was inhibited by all three phospholipases (Table 4). Phospholipase A completely abolished this chitinase activity. This effect was reversed in the presence of EGTA, which chelates the $\mathrm{Ca}^{2+}$ ions required for phospholipase A activity. (Phospholipases $\mathrm{C}$ and $\mathrm{D}$ do not require $\mathrm{Ca}^{2+}$ ions for activity.) Treatment with phospholipases $\mathrm{C}$ and $\mathrm{D}$ inhibited chitinase activity but did not completely abolish it under these conditions. 
Table 3. Proteolytic activities in the microsomal preparation from $M$. mucedo

\begin{tabular}{|c|c|c|}
\hline Peptide & Structure* & $\begin{array}{c}\text { Protease activity } \\
{\left[A_{405}(\mathrm{mg} \text { protein })^{-1}\right.} \\
\text { after } 20 \mathrm{~h}]\end{array}$ \\
\hline S-2484 & $<$ Glu-Pro-Val-pNA. $\mathrm{HCl}$ & $2 \cdot 61$ \\
\hline S-2238 & D-Phe-Pip-Arg- $p$ NA. $2 \mathrm{HCl}$ & $2 \cdot 35$ \\
\hline S-2337 & Bz-Ile-Glu-( $\gamma-O$-piperidyl)-Gly-Arg- $p$ NA. $\mathrm{HCl}$ & $1 \cdot 83$ \\
\hline S-2160 & Bz-Phe-Val-Arg- $p \mathrm{NA} . \mathrm{HCl}$ & 1.48 \\
\hline S-2444 & $<$ Glu-Gly-Arg-pNA.HCl & 0.61 \\
\hline S-2288 & D-Ile-Pro-Arg- $p$ NA . $2 \mathrm{HCl}$ & $0 \cdot 35$ \\
\hline S-2222 & Bz-Ile-Glu- $(\gamma-O-\mathrm{R})-\mathrm{Gly}-\mathrm{Arg}-p \mathrm{NA} . \mathrm{HCl}$ & 0 \\
\hline S-2251 & D-Val-Leu-Lys- $p \mathrm{NA} .2 \mathrm{HCl}$ & 0 \\
\hline S-2302 & D-Pro-Phe-Arg- $p \mathrm{NA} .2 \mathrm{HCl}$ & 0 \\
\hline
\end{tabular}

* Abbreviations: $p$ NA, p-nitroanilide; Bz, N-benzoyl; Pip, pipecolyl; <Glu, L-pyroglutamyl.

Table 4. Effect of phospholipases on chitinase activities from $M$. mucedo

Values are the means of at least 10 replicates \pm SE.

\section{Phospholipase added}

None

Phospholipase A

Phospholipase A +EGTA*

Phospholipase C

Phospholipase C + EGTA*

Phospholipase D

Phospholipase D+EGTA*

\begin{tabular}{|c|c|}
\hline \multicolumn{2}{|c|}{ Specific activity $\left[\mathrm{nmol} \min ^{-1}(\mathrm{mg} \text { protein })^{-1}\right]$} \\
\hline Supernatant preparation & Microsomal preparation \\
\hline $1 \cdot 16 \pm 0 \cdot 12$ & $1.58 \pm 0.01$ \\
\hline $\begin{array}{l}1 \cdot 14 \pm 0.08 \\
1.09 \pm 0.05\end{array}$ & $\begin{array}{r}0 \pm 0.05 \\
1.58 \pm 0.05\end{array}$ \\
\hline $\begin{array}{l}0.96 \pm 0.20 \\
0.96 \pm 0.13\end{array}$ & $\begin{array}{l}0.49 \pm 0.01 \\
0.34 \pm 0.12\end{array}$ \\
\hline $\begin{array}{l}1 \cdot 53 \pm 0.19 \\
1 \cdot 39 \pm 0.20\end{array}$ & $\begin{array}{l}0.19 \pm 0.02 \\
0.34 \pm 0.10\end{array}$ \\
\hline
\end{tabular}

* EGTA was added before the phospholipase.

These results suggest that microsomal chitinase has a phospholipid requirement. However, the phospholipases could be acting unspecifically by releasing inhibitory substances from the membrane. Two experiments were used to check this. In the first, equal volumes of supernatant and microsomes were preincubated in the same tube with phospholipase A. In the second, microsomes that had been pretreated with phospholipase $A$ were added to an equal volume of untreated supernatant. In both cases the preparations were then assayed for chitinase activity. The supernatant chitinase activity was not diminished in the mixtures, ruling out the possibility of an unspecific inhibition.

\section{DISCUSSION}

We have presented here the preliminary characterization of two forms of chitinase from $M$. mucedo. The supernatant chitinase activity is not a surprising finding, as such activities have been widely reported for fungi (Berkeley, 1979). It probably represents enzyme sequestered in lysosomal vacuoles (Iten \& Matile, 1970). The microsomal chitinase requires comment, as the results of its activation by proteases point to it being zymogenic, and its phospholipid requirement points to it being membrane-bound. It shares these two properties with the enzyme chitin synthase (Gooday \& Trinci, 1980). These common properties (and the apparent close association of the two enzymes in $M$. mucedo, currently under investigation) suggest that the enzymes might be regulated in consort to play a morphogenetic role during hyphal growth; i.e. that they represent the 'delicate balance between wall synthesis and wall lysis' (BartnickiGarcia, 1973). In vivo, the activation of the two zymogens would be expected to be specific. For fungal chitin synthases, the mechanism of activation still remains to be elucidated (Cabib et al., 
1979), but we have shown here that the microsomal preparations have several protease activities as possible contenders for the proposed endogenous activating factors for both chitin synthase and chitinase.

The endogenously activated microsomal chitinase was more stable than trypsin-treated preparations, as has been shown for chitin synthase from Candida albicans (Hardy \& Gooday, 1983). The inhibition of endogenous activation by PMSF suggests that this process is taking place by a serine protease, as is the case for chitin synthase activation in Saccharomyces cerevisiae. Ulane \& Cabib (1976) found that the protease responsible for chitin synthase activation was inhibited by PMSF, and that $1 \mathrm{~mol}$ PMSF reacted stoichiometrically with $1 \mathrm{~mol}$ protease to abolish activity. The slow rise in activity in Fig. 4 might indicate activation via a zymogenic serine protease that escaped initial inactivation by PMSF (c.f. zymogenic proteases in other fungi; North, 1982). In contrast to the microsomal preparation, the results of the effect of PMSF on the supernatant (Figs 3 and 4) suggest that in the supernatant there is a PMSFsusceptible serine protease activity that degrades this chitinase.

The relationship between the supernatant 'soluble' activity and the microsomal 'membranebound' activity remains to be elucidated. Wilson (1978) suggests that in some cases an enzyme molecule may be 'ambiquitous', reversibly switching between being soluble and being membrane-bound, its activity and regulation differing in the two states. We have no evidence one way or the other for whether this occurs with our two chitinases. In preliminary experiments we have detected a third state of the enzyme, as an extracellular enzyme released to the chitin agar medium, but its relationship to the other two forms has not been investigated.

We thank the AFRC for financial support and Dr K. Söderhall for the protease substrates.

\section{REFERENCES}

Achstetter, T., Ehmann, C. \& Wolf, D. H. (1980). New proteolytic enzymes in yeast. Archives of Biochemistry and Biophysics 207, 445-454.

AlgRanati, I. D. (1963). Determination of initial rates in enzymic non-linear progress reactions. Biochimica et biophysica acta 73, 152-155.

ARAKI, Y. \& ITO, E. (1975). A pathway of chitosan formation in Mucor rouxii. European Journal of Biochemistry 55, 71-78.

Aribisala, O. A. \& Gooday, G. W. (1978). Properties of chitinase from Vibrio alginolyticus as assayed with the chromogenic substrate 3,4-dinitrophenol-tetra$N$-acetyl- $\beta$-D-chitotetraoside. Biochemical Society Transactions 6, 568-569.

BARTNICKI-GARCIA, S. (1973). Fundamental aspects of hyphal morphogenesis. Symposia of the Society for General Microbiology 23, 245-267.

Bartnicki-Garcia, S. \& DAVIs, L. L. (1983). Chitosan synthesis in Mucor rouxii: mechanism and regulation. Abstracts of the 3rd International Mycological Congress, p. 15. Tokyo: Science Council of Japan.

Berkeley, R. W. C. (1979). Chitin, chitosan and their degradative enzymes. In Microbial Polysaccharides and Polysaccharases, pp. 205-236. Edited by R. C. W. Berkeley, G. W. Gooday and D. C. Ellwood. London: Academic Press.

BRADFORD, M. M. (1976). A rapid and sensitive method for the quantitation of microgram quantities of protein utilizing the principle of protein-dye binding. Analytical Biochemistry 72, 248-254.

Cabib, E., Duran, A. \& Bowers, B. (1979). Localized activation of chitin synthetase in the initiation of yeast septum formation. In Fungal Walls and Hyphal Growth, pp. 189-201. Edited by J. H. Burnett \& A. P. J. Trinci. Cambridge: Cambridge University Press.

Elango, N., Correa, J. U. \& Cabib, E. (1982). Secretory character of yeast chitinase. Journal of Biological Chemistry, 257, 1398-1400.

Gooday, G. W. \& Trinci, A. P. J. (1980). Wall structure and biosynthesis in fungi. Symposia of the Society of General Microbiology 30, 207-251.

Hardy, J. C. \& Gooday, G. W. (1983). Stability and zymogenic nature of chitin synthase from Candida albicans. Current Microbiology 9, 51-54.

Iten, W. \& Matile, P. (1970). Role of chitinase and other lysosomal enzymes of Coprinus lagopus in the autolysis of fruiting bodies. Journal of General Microbiology 61, 301-309.

Lopez-Romero, E., Ruiz-Herrera, J. \& BartNickIGaRCIA, S. (1982). The inhibitory protein of chitin synthase from Mucor rouxii is a chitinase. Biochimica et biophysica acta 702, 233-236.

Molano, J., Duran, A. \& Cabib, E. (1977). A rapid and sensitive assay for chitinase using tritiated chitin. Analytical Biochemistry 83, 648-656.

Muzzarelli, R. A. A., Tanfani, F., Scarpini, G. \& LATERzA, G. (1980). The degree of acetylation of chitins by gas chromatography and infrared spectroscopy. Journal of Biochemical and Biophysical Methods 2, 299-306.

NoRTH, M. J. (1982). Comparative biochemistry of the proteinases of eukaryotic microorganisms. Microbiological Reviews 46, 308-340. 
Polachek, I. \& Rosenberger, R. F. (1978). Distribution of autolysins in hyphae of Aspergillus nidulans: evidence for a lipid-mediated attachment to hyphal walls. Journal of Bacteriology 135, 741-747.

ROSENBERGER, R. F. (1979). Endogenous lytic enzymes and wall metabolism. In Fungal Walls and Hyphal Growth, pp. 265-277. Edited by J. H. Burnett \& A. P. J. Trinci. Cambridge: Cambridge University Press.
Ulane, R. E. \& CABIB, E. (1976). The activating system of chitin synthetase from Saccharomyces cerevisiae. Journal of Biological Chemistry 251, 33673374.

WILSON, J. E. (1978). Ambiquitous enzymes: variation in intracellular distribution as a regulatory mechanism. Trends in Biochemical Sciences 3, 124-125.

ZARAIN-HERZBERG, A. \& ARROYO-BEGOVICH, A. (1983). Chitinolytic activity from Neurospora crassa. Journal of General Microbiology 129, 3319-3326. 